\section{APP-149 尿管の神経支配について}

利根中央病院泌尿器科 ${ }^{1}$, 群馬大学大学院医学系研究科 器官代謝学講座泌尿器病態学2), 群馬大学大学院医学系 研究科器官機能制御学挐座器官譏能樓築学 ${ }^{31}$, 札幌医科 大学第二解剖学講座 ${ }^{4)}$, 帝京平成大学 5 ?

大木 一成 ${ }^{1}$, 黑川 公平 ${ }^{21}$, 武井 智幸 ${ }^{2}$, 依藤 宏 ${ }^{3}$, 佐藤 達夫 ${ }^{5)}$, 伊藤 一人 ${ }^{2)}$, 鈴木 和浩 ${ }^{2)}$

目的：最近、下部尿管結石に対する、Tamsulosin(アドレナリン作動性 $\alpha 1$ 受容体阻害薬) 投与の報告が散見される。Tamsulosin 投与により、 排石までの期間の短縮、排石率の向上が明らかとなるようである。Tamsulosinの作用点は、下腹神経および骨盤神経叢より尿管・膀胱へ分布 する豊富な交感神経の分枝であり、投与により尿管の驰緩が促進される ためであろうと推測されている。この作用点を詳細に解明する目的で、 解剖献体を用い尿管に分布する自律神経の神経解剖を行った。对象と方 法：男性 3 体の解剖標本について、自律神経の肉眼的神経解剖を行っ た。この結果、上部および中部尿管には、腹腔神経節および交感神経幹 よりのネットワーク状の分枝が見られた。更に下部尿管では下腹神経拉 よび骨篮神経叢から分布する豊富な分枝が見られた。次に男女各 1 体の 解剖標本を用い神経線維の識別を行うための神経解剖を行い、交感神経 幹・腹腔神経節・下腹神経叢・骨盤内䑏神経を同定した後、腎䐵・尿 管・膀胱までの連続標本を切り出した。現在、組織プレパラートを作成 L、HE 染色・免疫染色 (tyrosine hydroxylase) - 跹鞘染色 (luxor fast blue）を用い，交感神経幹・腹腔神経節・下腹神経趣および骨盤神経叢 から尿管に分布する神経を識別している。本報告ではわれわれの知り得 た康管の神経支配について詳細に報告する予定である。

\section{APP-150 ラットの前脳血流低下による排尿機能 の変化について}

\section{金沢大学医学部泌尿器科 \\ 四楖 智嗣, 小松 和人, 坚玉 浩一, 南 秀朗, 松谷 亮, 並木 幹夫}

【目的】老化に伴う排尿障害発生の中枢性機序を研究するため, ラットの前脳血流低下による排尿機能の変化について検討し た.【方法】12 週蹂 SD 崔性ラットを用い, ハロセン麻酔下に右 総頸動脈一外䫫静脈吻合し, 左総頸動脈を狭窄させ脳低灌流 ラット (CH rats)を作成した.コントロールとして総頝動脈を 剥離した偽手術群（SO rats）を用いた. 実験 1 ：手術 2 週後に 膀胱瘦を作成し膀胱内压測定を行い各パラメーターについて 比較した. 実験 $2:$ 手術 2, 4,8 週後に代謝ケージで排尿行動を 24 時間記録し, 1 回排尿量, 排尿回数につき比較した. 実験 3 ： 手術 8 週後にモリス型水迷路試験にて空間学習能について評 価した. 脳は TTC 染色を行い梗塞巣の有無を評価した. 【成 績】実験 $1: \mathrm{CH}$ rats 群の膀胱容量は有意に低下していた $(\mathrm{p}<$ 0.01 ). 実験 $2: \mathrm{CH}$ rats では手術 2 週間後より有意に平均 1 回 排尿量は低下し $(\mathrm{p}<0.05)$, 排尿回数を増加していた $(\mathrm{p}<0.05)$. 実験 $3: \mathrm{CH}$ rats 群では空間認知学習能が有意に低下していた ( $\mathrm{p}<0.05)$. CH rats に麻疩は認めず, TTC 染色では明らかな梗 塞巣を認めなかった. 結論】運動障害を呈さず, 梗塞を起こさ ないレベルの前脳血流の低下で記憶障害がおこり, 膀胱容量は 低下した. 加齢に伴う過活動膀胱発生の一部に動脈硬化などに よる脳血流低下が関与している可能性が推測された。
APP-151 ラット膀胱における上皮性ナトリウム チャネルの局在：膀胱上皮と知觉神経 終末

山梨大学大学院医学工学総合研究部泌尿器科学
都書棋, 荒木 勇雄, 三神 裕䄫, 座光寺 秀典,

古谷 泰久, 武田 正之

【目的】上皮性ナトリウムチャネル (Epithelial $\mathrm{Na}^{+} \mathrm{Channel}: \mathrm{ENaC}$ )は、 膀脱知覚神経路におけるメカノセンサーの有力な候補分子である。 我々は、ENaCがヒトおよびラットの膀胱上皮細胞に存在し、ヒト閉塞 膀脱においてその発現が元進することを報告した。一方、 $\mathrm{ENaC}$ は後根 神経節緗胞にも存在することが報告されている。今回、膀脱上皮直下 を走行する知覚神経終末における $\mathrm{ENaC}$ の発現の有無を検討した。

【方法】 10 週令 SD 種崔ラットから摘出した膀胱及び後根神経節を凍 結保存し、8 $\mu \mathrm{m}$ のスライス標本を作製した。 $\mathrm{ENaC}$ 各サブュニット $(\alpha, \beta, \gamma)$ に対する抗体およびCGRP 抗体を用いた二重免疫蛍光染色 を行い、共焦点レーザー影微鏡を用いて、それぞれの局在につき検討 した。

【成績】 $\mathrm{ENaC}$ 各サブユニットは膀胱上皮細胞に存在するばかりでな く、膀脱上皮層直下を走行する CGRP 含有知覚神経終末にも存在する ことか確認された。また、後根神経節細胞においても、 $\mathrm{ENaC}$ 各サブユ ニットが存在し、CGRP含有細胞以外にもその発現が確認された。

【結論】ENaC 注膀胱上皮ばかりでなく、膀胱上皮に進入する知覚神経 終末(C 線維)にも、その存在が確認された。膀羘知覚神経路における Mechano-Sensory Transductionにおいて、 $\mathrm{ENaC}$ が何らかの役割を 演じている可能性が示唆される。

\section{APP-152 シクロヘキサノン誘浔体の梼尿病ラッ

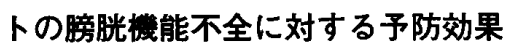

\section{鳥取大学医学部分子薬理学1，明治乳業医薬事業部 ${ }^{2}$, 鳥 取大学医学部泌尿器科}

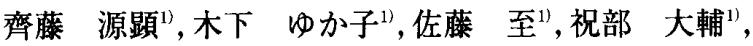
鈴木 啓仁 ${ }^{21}$, 山田 昌司 ${ }^{2)}$, 宮川 征男 ${ }^{2)}$, 佐藤 慶祐 ${ }^{11}$ 【目的】シクロヘキサノン誘導体は神経細胞の誘導、分化および保 護作用が知られている。今回 STZ 誘発ラット糖尿病モデルを作成 し、シクロヘキサノン誘導体の予防効果を検討した。【方法】8 週齢 雄 SD ラットにSTZ $(50 \mathrm{mg} / \mathrm{kg}$, i.p.) にて糖尿病を誘発した。 4 群(コントロール群、糖尿病群、糖尿病にシクロヘキサノン誘導体 $(2 \mathrm{mg} / \mathrm{kg})$ 投与群、糖尿病群にシクロヘキサノン誘導体 $(8 \mathrm{mg} / \mathrm{kg})$ 投与群)に分け、各群 8 週間飼育した $(n=6-8)$ 。シクロヘキサノ ン誘導体は 1 日 1 回連続腹腔内投与した。各群 8 週間飼育後、メ夕 ボリックケージを用いた voiding behavior study、ウレタン麻酔下

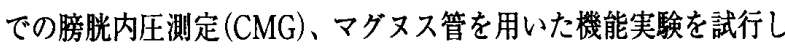
た。【成績】シクロヘキサノン誘導体は、糖尿病にお污る体重、血糖 值、血清インスリン值および 1 日の排尿量、排尿回数に対して変化 を与えなかった。しかし、排尿時最大膀胱内圧および残尿量を用量 依存性に改善した。糖尿病ラット膀胱ではカルバコールに対する 収縮反応は増強したが、 $\mathrm{KCl}$ に対する収縮反応は変化がなかった。 シクロヘキサノン誘導体治療群では増大した収縮反応が用量依存 的に抑制された。結論】シクロへキサノン誘導体は糖尿病におい て血糖値および血清インスリン值は変化させないが、糖尿病性膀 胱機能障害を改善することが示唆された。 